\title{
INFILTRASI DAN PERMEABILITAS PADA TANAH REKLAMASI TAMBANG EMAS
}

\section{INFILTRATION AND PERMEABILITY IN RECLAIMED GOLD MINEDLAND}

\author{
Liskawani Tambunan'), Jailani Husain2) dan Joice M.J. Supit') \\ 1)Mahasiswa Program Studi Agroekoteknologi, Fakultas Pertanian Unsrat Manado, 95115 \\ 2)Dosen Program Studi Agroekoteknologi, Fakultas Pertanian Unsrat Manado, 95115 \\ Email:liskawani.tambunanaet14@gmail.com
}

\begin{abstract}
Infiltration and permeability are soil parameters that can be used to describe the extent of land damage caused by the mining process. In accordance with Law No. 4.0 of 2009 on Mineral and Coal Mining, that reclaiming mining land is obligatory for every company that manages it. This study aims to determine the rate of infiltration and permeability on the reclaimed gold mined land. The research was conducted at the gold mining location of Bakan and Lanut. Infiltration measurements were carried out on straight line transect along the foot slope to the top slope. Measurements were made at two meter distance in 5 $\mathrm{cm}$ depth along the transect line direction using the Guelph Permeameter. Hydraulic conductivity was calculated from infiltration data. This research revealed that reclamation has positive effect in increasing of infiltration rate and permeability. Crop dan root growth should have contributed in increasing soil organic matter, root and microbial activities, which leads to improve soil texture and soil structure.
\end{abstract}

Keywords: infiltration, permeability, reclaimed

\begin{abstract}
ABSTRAK
Infiltrasi dan permeabilitas merupakan parameter tanah yang bisa digunakan untuk menggambarkan tingkat kerusakan tanah akibat proses penambangan. Sesuai UU No 4. Tahun 2009 tentang Pertambangan Mineral dan Batubara, bahwa mereklamasi lahan bekas tambang merupakan kewajiban bagi setiap perusahaan yang mengelola tambang tersebut. Penelitian ini bertujuan untuk mengetahui laju infiltrasi dan permeabilitas pada tanah reklamasi tambang emas. Penelitian ini dilaksanakan di lokasi pertambangan emas Bakan dan Lanut. Pengukuran infiltrasi dilaksanakan dengan metode transek pada sebuah garis lurus sepanjang kaki lereng, punggung hingga puncak. Pengukuran dilakukan pada jarak tiap dua meter mengikuti arah garis. Pengukuran infiltrasi dilakukan satu kali pada kedalaman $5 \mathrm{~cm}$ di tiap titik pengukuran menggunakan alat Guelph Permeameter. Hasil penelitian ini menunjukkan bahwa reklamasi dan revegetasi memberikan pengaruh positif terhadap peningkatan laju infiltrasi dan permeabilitas oleh pertumbuhan tanaman revegetasi yang menyumbang bahan organik pada tanah sehingga memperbaiki tekstur dan struktur tanah.

Kata kunci: infiltrasi, permeabilitas, reklamasi
\end{abstract}




\section{PENDAHULUAN}

Sektor pertambangan merupakan salah satu penggerak roda perekonomian dan pembangunan nasional terbesar termasuk tambang emas yang dimiliki Indonesia baik sebagai sumber energi maupun sumber devisa negara. Hal tersebut menjadikan emas sebagai salah satu sumber daya yang bernilai tinggi yang mampu mendongkrak perekonomian suatu negara, sehingga mendorong berbagai pihak untuk melakukan eksploitasi pada lahan tambang.

Kegiatan penambangan dapat merubah kondisi lingkungan pada lokasi penambangan. Tambang emas di Indonesia umumnya dilakukan dengan sistem tambang terbuka yaitu dengan mengupas lapisan tanah pucuk dan batuan yang ada di atasnya sampai pada lapisan yang mengandung emas. Kegiatan pengupasan dan pemindahan lapisan tanah pucuk dan batuan berdampak pada kerusakan lingkungan antara lain hilangnya vegetasi hutan, flora dan fauna, lapisan tanah, rusaknya sifat-sifat tanah (fisik, kimia, dan biologi) serta membentuk lereng-lereng terjal yang rentan terhadap longsoran dan mengubah kondisi hidrologis dan kesuburan tanah.

Penurunan kualitas tanah menjadi masalah paling besar dari kerusakan lingkungan yang ditimbulkan dalam proses penambangan. Adapun berbagai kerusakan lingkungan yang diakibatkan dalam proses penambangan seperti: kerusakan tanah, air, udara, laut, serta hutan. Rusaknya tanah disebabkan, karena sampai pada saat setelah bahan-bahan tambang dieksploitasi, lahan tambang tersebut akan mengalami perubahan topografi, vegetasi penutup tanah, pola hidrologi, dan kerusakan tubuh tanah, bahkan sampai terbentuk lubang-lubang bekas tambang, oleh karena itu pemerintah mewajibkan setiap perusahaan tambang emas untuk melakukan reklamasi bekas tambang dengan cara revegetasi.

Reklamasi tanah bekas tambang dilakukan dengan beberapa tahapan. Areal reklamasi dilakukan dengan menata tanah timbunan dan dilakukan penaburan dengan tanah pucuk. Areal tersebut harus segera diberikan lapisan penutup tanah seperti mulsa dan penanaman vegetasi penutup tanah untuk mengurangi dispersi hujan pada permukaan tanah. Usaha revegetasi dengan memanfaatkan tanaman asli lokal, tanaman pioner, atau tanaman lainnya lebih mudah dilakukan dalam mempercepat keberhasilan reklamasi. Hasil reklamasi diharapkan dapat memberi dampak positif terhadap perbaikan kualitas fisik seperti bobot isi, porositas, kemampuan tanah dalam menahan air, pergerakan air dalam tanah, serta kualitas kimia seperti bahan organik dan $\mathrm{pH}$ tanah.

Kapasitas infiltrasi dan permeabilitas merupakan parameter tanah yang bisa digunakan untuk melihat kerusakan tanah akibat adanya kegiatan penambangan. Kapasitas infiltrasi ratarata berkorelasi dengan sifat-sifat fisik tanah korelasi adalah positif terhadap porositas tanah dan kandungan bahan organik, dan negatif terhadap kandungan liat dan berat isi tanah. Berkurangnya pori-pori tanah yang umumnya disebabkan oleh pemadatan saat melakukan reklamasi dapat menyebabkan terhambatnya air yang akan masuk kedalam tanah (Lee, 1990).

Kabupaten Bolaang Mongondow merupakan salah satu daerah di Sulawesi Utara sebagai pusat kegiatan penambangan emas. Apabila lahan bekas tambang tidak dikelola dengan baik maka akan menimbulkan dampak negatif antara lain rusaknya sifat-sifat fisik tanah dan terganggunya tata air. Keadaan seperti itu terjadi pada hampir semua lokasi lahan bekas tambang.

Penelitian ini bertujuan untuk mengetahui pengaruh reklamasi tambang emas terhadap infiltrasi dan permeabilitas.

\section{METODE PENELITIAN}

Penelitian ini dilaksanakan di pertambangan Emas JResources Bolaang Mongondow (JRBM) yang berlokasi di Bakan yaitu: Pit Osela dan Pit Lanut: waste dump Agus A, waste dump Agus B, dan waste dump Nala A dengan waktu 2 bulan, dimulai dari bulan Desember 2017 - Januari 2018.

Alat yang digunakan dalam penelitian ini adalah Google earth, GPS, Abney hand level, pita ukur, Guelph permeameter, kamera, loup, kantong air, stop-watch, alat tulis, seperangkat komputer, bor tanah, tali rafia, dan kamera. Bahan yang di- 
gunakan adalah, tanah dan air. Penelitian ini merupakan penelitian lapangan dengan menggunakan metode transek dan pengukuran sepanjang sebuah transek pada katena berlereng datar hingga sangat curam yang berisi berbagai jenis penggunaan tanah.

Pelaksanaan penelitian ini terdiri dari beberapa kegiatan di lapangan yang meliputi: pengukuran infiltrasi dilaksanakan pada sebuah garis lurus sepanjang kaki lereng, punggung hingga puncak. Pengukuran dilakukan pada jarak tiap dua meter mengikuti arah garis. Pengaruh lereng dan penggunaan tanah dideteksi pada garis lurus yang searah lereng. Kemiringan lereng ditentukan dengan alat Abney hand level, dan panjang lereng

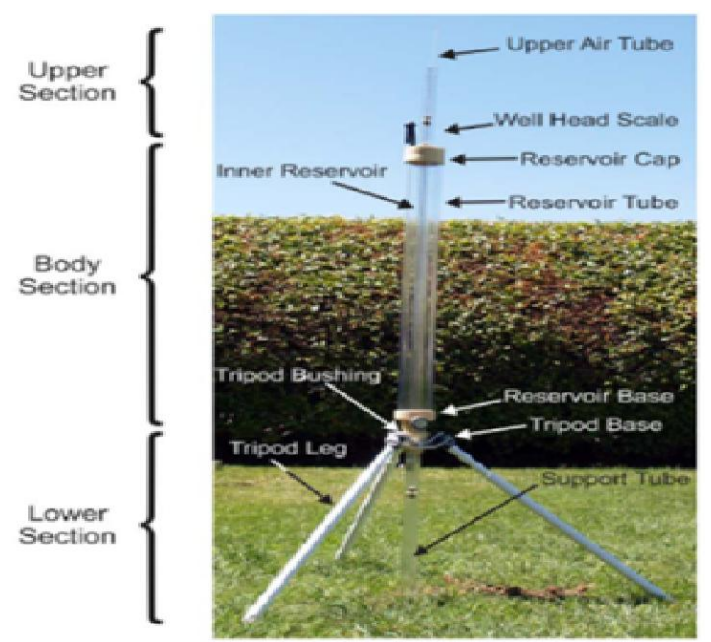

Gambar 1. Detil Guelph Permeameter

(Figure 1. Detailed Guelph Permeameter)

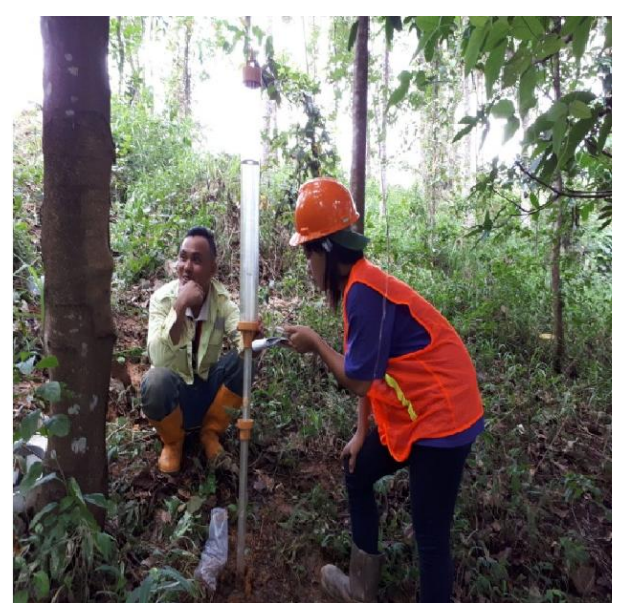

Gambar 2. Pengukuran Infiltrasi di Lapangan (Figure 2. Infiltration Measurements in the Field) diukur langsung di lapangan dengan meteran. Pengukuran infiltrasi dilakukan 1 kali ditiap titik pengukuran menggunakan alat Guelph Permeameter (Gambar1). Pengukuran dilakukan dengan cara (1) membuat lubang pada tanah sedalam $0-5 \mathrm{~cm}$ dengan menggunakan bor tanah berdiameter $6 \mathrm{~cm}$, (2) meletakkan Guelph Permeameter dengan posisi tegak tepat di atas lubang lalu mengisi air pada lubang reservoir, (3) menyetel inlet udara tabung reservoir untuk menentukan tinggi genangan, (4) membaca dan mencatat selisih perubahan tinggi permukaan air pada tabung reservoir hingga keadaaan konstan. Cara tersebut dilakukan juga pada titik-titik pengukuran berikutnya. 
Tekstur tanah ditentukan di lapang yaitu memijat tanah basah di antara ibu jari dan telunjuk, sambil dirasakan halus kasarnya yaitu dirasakan adanya butir-butir pasir, debu dan liat (Hardjowiegono, 2007). Menetapkan tipe struktur dengan menggunakan kaca pembesar (Loup) lalu melihat bentuknya sesuai dengan penuntun lapangan.

\section{Analisis Data}

Data hasil pengukuran di lapangan digunakan untuk menentukan laju infiltrasi, dan permeabilitas menurut Husain (1993) sebagai berikut:

$I=\frac{Q}{A}$

dimana I = laju infiltrasi $\left(\mathrm{m} . \mathrm{s}^{-1}\right)$

$Q=$ volume air yang masuk ke dalam $\operatorname{tanah}\left(\mathrm{m}^{3} \cdot \mathrm{s}^{-1}\right)$

$A=$ luas penampang bor tanah $\left(\mathrm{m}^{2}\right)$

Penghitungan permeabilitas, digunakan rumus menurut Reynold et. a.l (1992) sebagai berikut:

$$
\begin{aligned}
& K_{s}=\frac{C Q_{s}}{\left[2 \pi H^{2}+C \pi \alpha^{2}+\frac{2 \pi H}{\alpha{ }^{*}}\right]} \\
& \text { dimana } \mathrm{K}=\text { permeabilitas }\left(\mathrm{m} \cdot \mathrm{s}^{-1}\right) \\
& \mathrm{C}=1,33 \\
& \pi=3,14 \\
& \alpha^{*}=0,12 \\
& \mathrm{a}=\text { radius bor }(\mathrm{m}) \\
& \mathrm{H}=\text { tinggi genangan }(\mathrm{m})
\end{aligned}
$$

\section{HASIL DAN PEMBAHASAN}

\section{Laju Infiltrasi dan Permeabilitas Laju Infiltrasi}

Laju infiltrasi adalah volume air yang masuk ke dalam tanah melalui permukaan tanah. Hasil pengukuran laju infiltrasi pada masing-masing transek adalah sebagai berikut.

\section{Lokasi Waste Dump Osela}

Hasil pengukuran laju infiltrasi pada titik 1 (puncak lereng) hingga titik 25 (kaki lereng) dengan jarak antara 2 titik sepanjang 2 meter di lokasi waste dump Osela ditunjukkan pada (Gambar 3).

Pada 6 meter puncak lereng infiltrasi tergolong sedang lambat, kemudian meningkat menjadi tinggi pada 10 meter lalu turun lagi menjadi sedang lambat pada 12 meter berikutnya, lalu semakin menjadi sangat lambat pada 18 meter berikutnya, lalu meningkat menjadi sedang cepat pada 32 meter berikutnya, dan akhirnya menjadi lambat pada 48 meter terakhir di kaki lereng. Infiltrasi sedang lambat pada 6 meter di puncak lereng karena pada tanah tersebut terbuka, tidak ditumbuhi banyak vegetasi hanya sedikit rumput, dan mungkin karena berada di punggung sering dipijak pekerja sehingga tanah padat. Menurut Utomo (1994) dalam Irsyamudana (2000) keadaan tanah yang terbuka diikuti pengangkutan bahan organik dan pemadatan tanah menyebabkan infiltrasi rendah. Pada jarak 10 meter infiltrasi tinggi karena permukaan tanahnya banyak bahan organik hasil pelapukan tanaman, banyak akar, tanah gembur tidak padat, dan struktur yang remah serta tekstur lempung liat berpasir. Menurut Susanto (2005) adanya bahan organik dalam tanah akan memperbaiki sifat fisik, kimia, dan biologi tanah seperti menurunkan kepadatan tanah yang menyebabkan kemampuan mengikat air dalam tanah tinggi. Pada jarak 18 meter infiltrasi lambat terlihat di lapangan tanahnya dalam keadaan lembab mungkin karena pengaruh vegetasi yang menutupi permukaan tanah sehingga kondisi tanah terlalu lembab. Prijono (2008) mengemukakan, bahwa umumnya infiltrasi akan besar pada saat tanah masih kering. Pada jarak 48 meter di kaki lereng infiltrasi menjadi lambat karena merupakan daerah tanggul permukaan tanah keras terlihat bahan organik sedikit. Nilai rata-rata laju infiltrasi di lokasi Osela sebesar $38.21 \mathrm{~cm} / j a m$ tergolong sedang (Kohnke, 1986). Laju infiltrasi tertinggi $163 \mathrm{~cm} / \mathrm{jam}$ pada titik pengukuran 5 diidentifikasi pada kondisi permukaan tanah yang gembur dengan struktur yang remah, terlihat secara visual pertumbuhan tanaman revegetasi, dan terdapatnya fauna dan akar tanaman yang sudah membusuk. Menurut Sofyan $d k k$ (2017) peningkatan laju infiltrasi disebabkan oleh pertumbuhan tanaman revegetasi yang dapat memperbaiki struktur tanah melalui 
aktivitas perakaran dan sumbangan bahan organik. Titik 6 dan 16 mempunyai laju infiltrasi sama besar yaitu $108 \mathrm{~cm} / \mathrm{jam}$ tergolong sedang cepat dan terendah dititik 9 yaitu $0.5 \mathrm{~cm} / \mathrm{jam}$ tergolong sangat lambat dan titik 23 mempunyai nilai infiltrasi 0 . Sebaliknya infiltrasi terendah pada titik 9 dengan topogafi dan penggunaan tanah yang sama, walapun terdapat vegetasi tapi terbukti dari pengamatan yang dilakukan permukaan tanahnya tidak mengandung banyak seresah, dengan tekstur lempung berpasir dan struktur remah hal ini mungkin karena kondisi lereng yang agak curam. Menurut Arsyad (2010) kecuraman lereng, dan bentuk lereng akan mempengaruhi besarnya erosi, sehingga infiltrasi menurun. Infiltrasi 0 terjadi pada titik 23 , hal ini karena terdapat saluran yang berisi air sehingga tanah jenuh sehingga sulit menyerap air (Prijono, 2008), di samping itu melalui hasil identifikasi mempunyai tekstur lempung liat berpasir dan tidak berstruktur.

\section{Lokasi Waste Dump Agus A}

Hasil pengukuran laju infiltrasi pada 11 titik di lokasi waste dump Agus A ditunjukkan pada (Gambar 4).

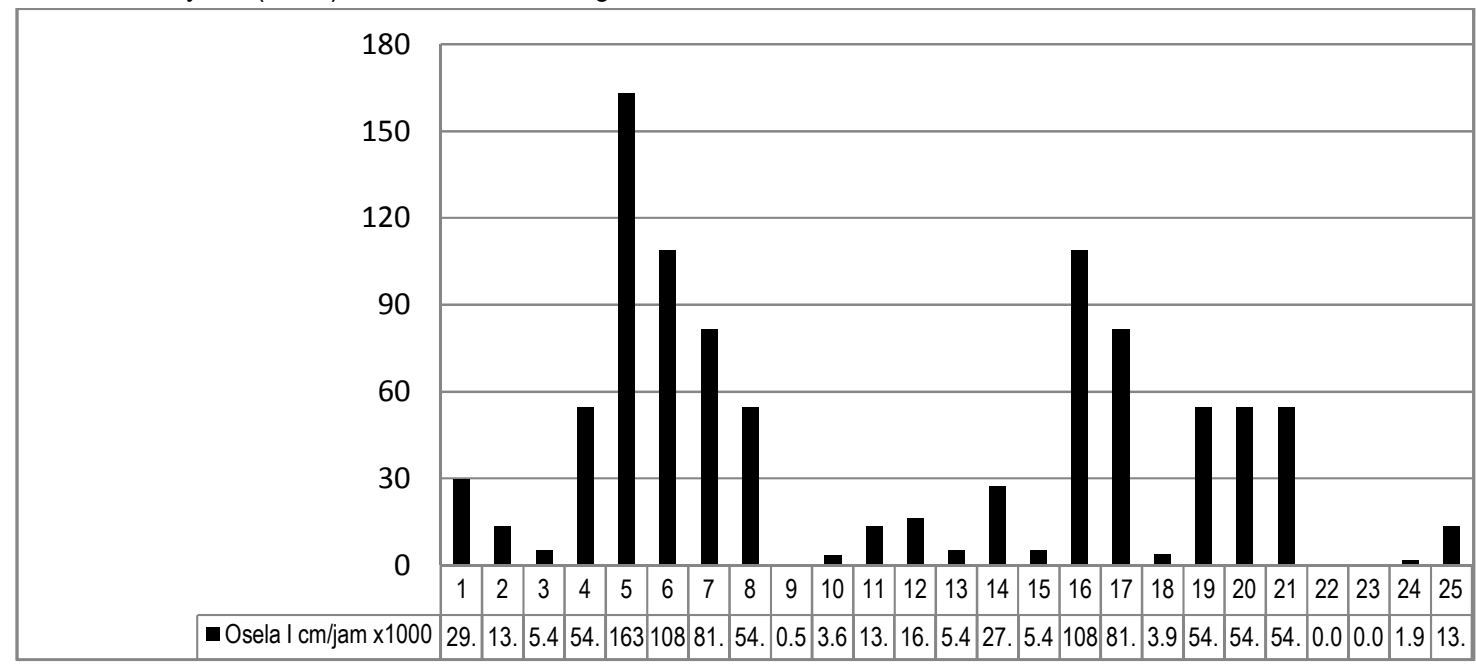

Gambar 3. Laju Infiltrasi pada Transek Pertama Titik 1 sampai 25 Waste Dump Osela

(Figure 3. Infiltration Rate at First Transect Point 1 to 25 Waste Dump Osela)
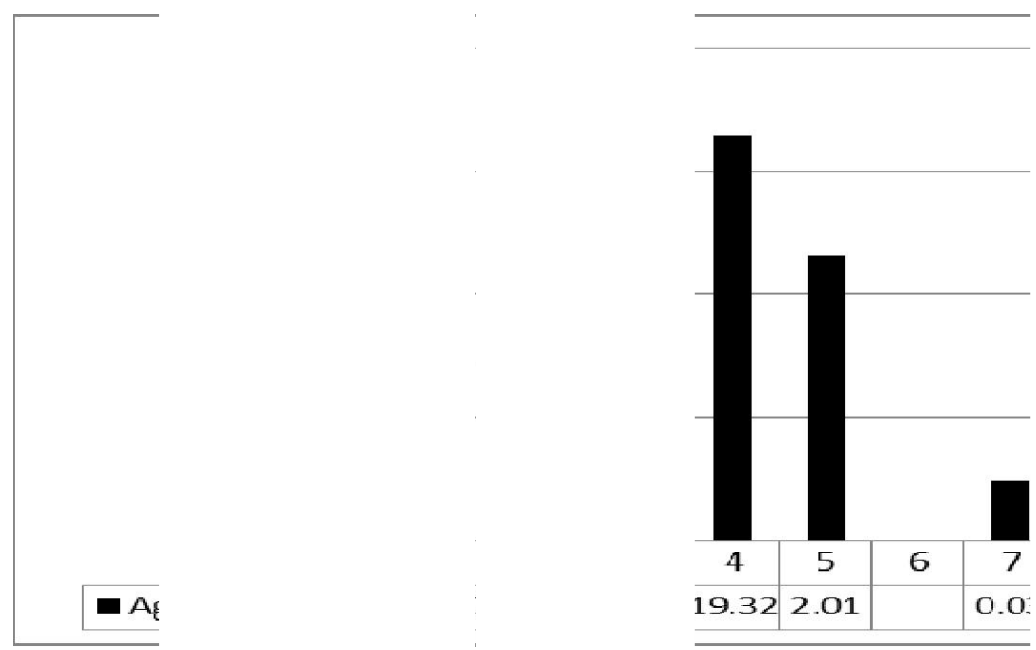

Gambar 4. Laju Infiltrasi pada Transek Kedua Titik 1 sampai 11 Waste Dump Agus A

(Figure 4. Infiltration Rate at First Transect Point 1 to 11 Waste Dump Agus A) 
Pada 2 meter puncak lereng infiltrasi tergolong sangat lambat, kemudian naik menjadi lambat pada 6 meter lalu meningkat lagi menjadi sedang lambat pada 8 meter dan terakhir menjadi sangat lambat pada 22 meter di kaki lereng. Nilai rata-rata laju infiltrasi di lokasi Agus A sebesar 2.39 $\mathrm{cm} / j a m$ tergolong Lambat (Kohnke 1986). Infiltrasi tertinggi terjadi dititik 4 yaitu sebesar 19.32 tergolong sedang lambat (Kohnke 1968) dan infiltrasi terendah terjadi dititik 2 yaitu 0.02 tergolong sangat lambat. Secara visual tingginya infiltrasi yang terjadi pada titik 4 ini kemungkinan didukung oleh vegetasi yaitu hasil pembusukan dari batang, ranting, dan daun dari vegetasi berkayu tersebut yang memberikan sumbangan bahan organik bagi tanah (Bachtiar, 2011), tetapi bahan organik tersebut belum memberikan dampak terhadap pembentukan struktur dan tekstur tanah yang baik karena mungkin kondisi tanah yang curam sehingga bahan organik terangkut saat hujan. Menurut Utomo (1994) dalam Irsyamudana (2000) pengangkutan bahan organik menyebabkan kapasitas infiltrasi tanah rendah. Terbukti di lahan tersebut adalah tekstur lempung berdebu dengan struktur gumpal. Hal ini kemungkinan karena lahan ditumbuhi vegetasi berkayu yang menyebabkan tanah dalam keadaan lembab, juga kondisi lereng yang curam mengakibatkan bahan organik ikut terbawa air pada saat hujan. Sebaliknya, rendahnya infiltrasi dititik 2 karena seresah dari daun, batang, ranting sangat sedikit memberikan pengaruh terhadap struktur tanah. Struktur tanah pada titik tersebut adalah gumpal dengan tekstur liat berdebu. Titik 8, 9, 10 mempunyai nilai permeabilitas 0 , hal ini karena secara visual kondisi tanah lembab, kadar air tanah tinggi dengan struktur gumpal dan tekstur liat. Hal ini sesuai dengan pendapat Arsyad (2010), yang menyatakan bahwa semakin tinggi kadar air tanah, maka laju infiltrasi semakin berkurang, dan akan mencapai laju minimum yang konstan.

\section{Lokasi Agus B}

Hasil pengukuran laju infiltrasi pada 5 titik di lokasi Waste Dump Agus B ditunjukkan pada (Gambar 5).

Pada 2 meter puncak lereng infiltrasi tergolong lambat, kemudian meningkat menjadi sedang lambat pada 6 meter terakhir turun lagi menjadi sangat lambat pada 10 meter di kaki lereng. Nilai rata-rata laju infiltrasi di lokasi Agus B sebesar $2.40 \mathrm{~cm} / \mathrm{jam}$ tergolong lambat (Kohnke 1986). Infiltrasi tertinggi terjadi dititik pengukuran 3 yaitu $5.41 \mathrm{~cm} / \mathrm{jam}$, dan titik pengukuran $4,5 \mathrm{mem}$ punyai nilai infiltrasi sama yaitu $1.08 \mathrm{~cm} / \mathrm{jam}$ dan terendah dititik pengukuran 2 yaitu $0.17 \mathrm{~cm} / \mathrm{jam}$ diidentifikasi pada penggunaan tanah rumput dengan umur yang tergolong muda 1 tahun, tekstur liat berdebu. Secara visual tanah tersebut masih terbuka, terbongkar, belum sepenuhnya ditumbuhi vegetasi rumput, kecilnya tanaman sebagai penutup tanah kemungkinan tidak dapat melindungi tanah dari pukulan butir-butir hujan yang terhempas sehingga tanah mudah hancur. Menurut Rejntjes (2003) penutupan tanah oleh tanaman akan mengabsorbsi butir-butir hujan yang terhempas dengan efektif dalam mempertahankan laju infiltrasi. Tanahtanah yang agregatnya stabil akan menjaga kapasitas infiltrasi tetap tinggi (Arsyad, 2010).

\section{Lokasi Waste Dump Nala}

Hasil pengukuran laju infiltrasi pada 13 titik di lokasi Waste Dump Nala ditunjukkan pada (Gambar 6). 

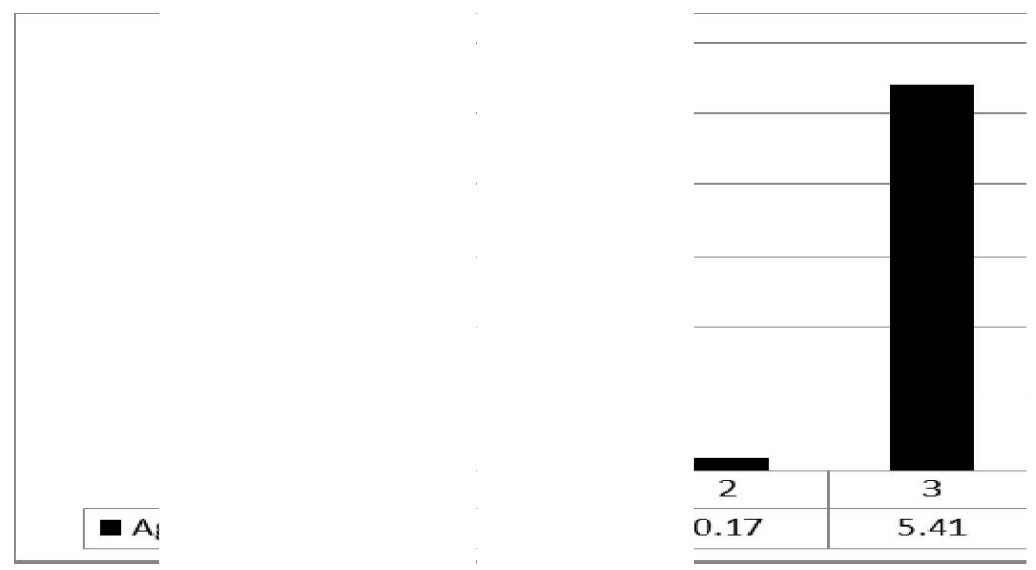

Gambar 5. Laju Infiltrasi pada Transek Ketiga Titik 1 sampai 5 Waste Dump Agus B

(Figure 5. Infiltration Rate at First Transect Point 1 to 5 waste Dump Agus B)
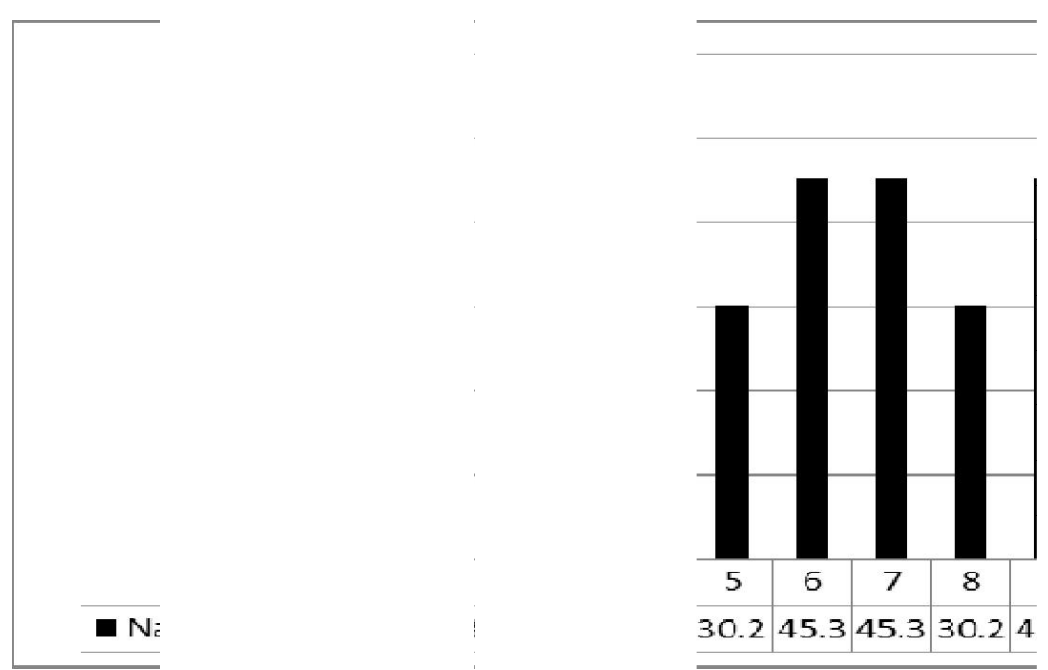

Gambar 6. Laju Infiltrasi pada Transek Keempat Titik 1 sampai 13 Waste Dump Nala

(Figure 6. Infiltration Rate at First Transect Point 1 to 25 waste Dump Nala)

Pada 2 meter puncak lereng infiltrasi tergolong sedang lambat, kemudian meningkat menjadi sedang pada 6-22 meter berikutnya, kemudian kembali menjadi sedang lambat pada 26 meter terakhir di kaki lereng. Nilai rata-rata laju infiltrasi di lokasi Nala sebesar $29.5 \mathrm{~cm} / \mathrm{jam}$ tergolong sedang (Kohnke 1986). Dari grafik terlihat bahwa infiltrasi tertinggi terjadi pada titik pengukuran 10 yaitu 48.3 $\mathrm{cm} / \mathrm{jam}$ dan yang terendah pada titik 1 yaitu 10.8 $\mathrm{cm} / j a m$. Tingginya infiltrasi pada titik 10 kemungkinan karena vegetasi disini sangat rapat terlihat dari rumput yang saling merambat, kondisi tanahnya juga gembur, dan banyak mengandung bahan organik terbukti struktur tanahnya juga remah. Me- nurut Liedloff (2003) semakin rapat dan beraneka ragam vegetasi berperan dalam melindungi permukaan tanah dari butir air sehingga kekuatan menghancurkan tanah berkurang dan meningkatkan infiltrasi. Infiltrasi terendah terdapat dititik 1 kemungkinan penyebabnya karena dekat dengan jalan sering dipijak pekerja sehingga tanah padat.

\section{Permeabilitas}

Permeabilitas tanah adalah kecepatan air menembus tanah pada periode tertentu. Hasil pengukuran permeabilitas pada masing-masing transek adalah sebagai berikut. 


\section{Lokasi Waste Dump Osela}

Hasil pengukuran permeabilitas pada 25 titik di lokasi Waste Dump Osela ditunjukkan pada (Gambar 7).

Pada 2 meter puncak lereng permeabilitas tergolong cepat, kemudian menurun agak lambat pada 4 meter berikutnya, lalu meningkat menjadi sangat cepat pada 6 meter berikutnya, dan terus terjadi peningkatan pada 10 meter berikutnya menjadi sangat cepat, pada jarak 12 meter berikutnya meningkat lagi, dan pada 18 meter berikutnya menjadi sangat lambat, terakhir pada jarak 48 meter ke arah kaki lereng menjadi sangat lambat. Kondisi ini menunjukkan adanya keragaman permeabilitas sepanjang transek. Berdasarkan klasifikasi hantaran hidrolik tanah menurut Unhland dan O'neal (1951), nilai permeabilitas hasil pengukuran di laboratorium pada masing-masing lahan yaitu termasuk ke dalam kelas cepat untuk lahan hutan sekunder dan lahan pertanian konservasi, lahan pertanian intensif termasuk ke dalam kelas agak cepat, dan lahan semak termasuk ke dalam kelas sedang. Permeabilitas pada hutan sangat tinggi, hal ini dikarenakan banyaknya pori-pori berukuran besar dan kontinu yang terbentuk oleh aktivitas perakaran dari vegetasi di lahan ini, yang mana hal ini menyebabkan aliran air menjadi sangat tinggi.
Nilai rata-rata permeabilitas di lokasi Osela sebesar $14.48 \mathrm{~cm} / \mathrm{jam}$ tergolong sedang sampai cepat kriteria (Hammer, 1978). Permeabilitas tanah pada transek pertama menunjukkan bahwa pada titik pengukuran 6 merupakan permeabilitas dengan nilai tertinggi yaitu $1.134 \mathrm{~cm} / \mathrm{jam}$ tergolong cepat dan permeabilitas terendah pada titik 9 yaitu 0.1 $\mathrm{cm} / \mathrm{jam}$ tergolong lambat kriteria (Hammer, 1978). Besarnya permeabilitas pada titik 6 kemungkinan disebabkan karena pada tanah permukaan terdapat banyak bahan organik, juga didukung oleh struktur tanah yang remah dan tekstur lempung liat berpasir. Tanah berpasir mempunyai ukuran partikel yang besar sehingga porositasnya bagus. Tanah yang mempunyai ukuran partikel besar dan pori besar, maka permeabilitasnya tinggi ( $N$. Suharta dan B.H Prasetyo, 2008). Rendahnya permeabilitas tanah pada titik 9 sebesar 0.1 , karena infiltrasi permukaan tanah juga rendah mungkin karena tanah cukup lembab. Titik 23 dan 24 mempunyai nilai permeabilitas 0 , karena pada titik ini merupakan saluran yang berisi air.

\section{Lokasi Agus A}

Hasil pengukuran permeabilitas pada 11 titik di lokasi Agus A ditunjukkan pada (Gambar 8).
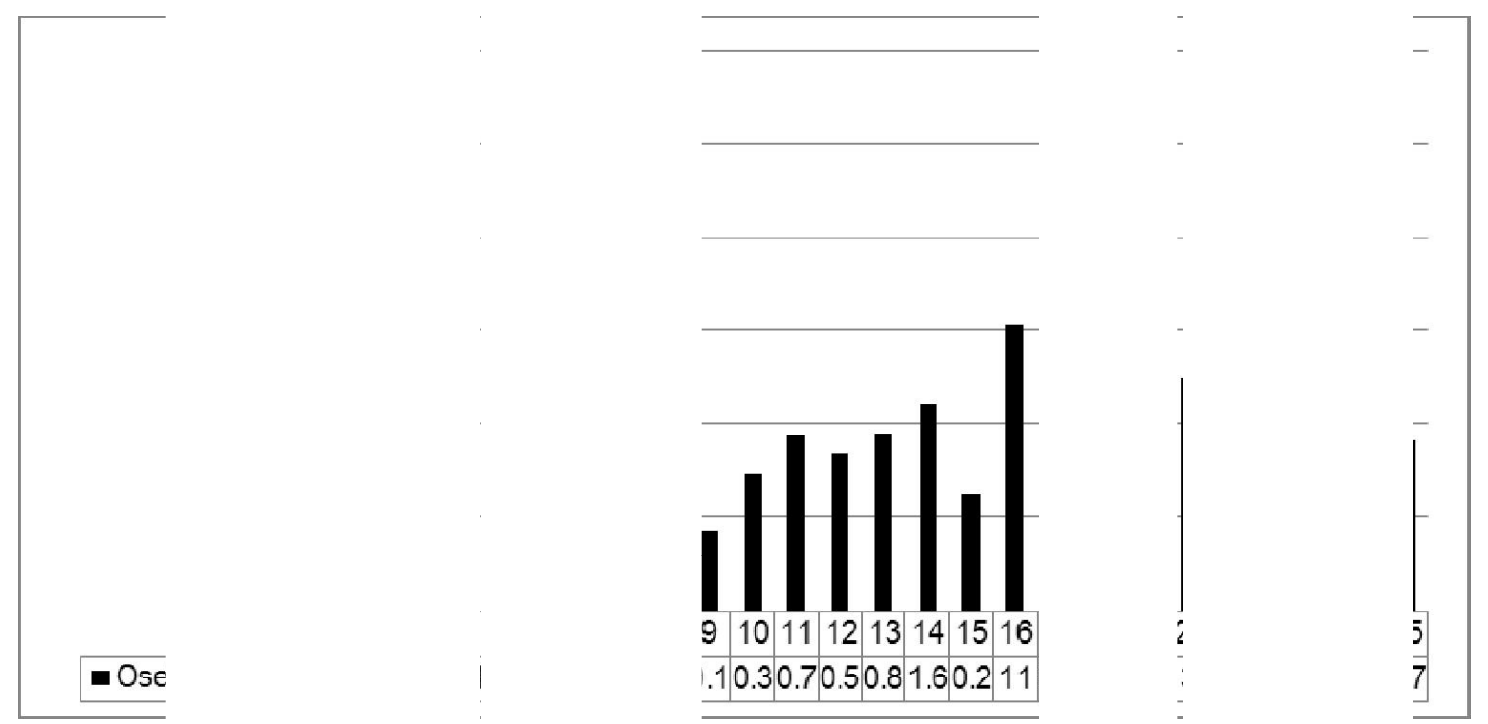

Gambar 7. Permeabilitas pada Transek Pertama titik 1 sampai 25 Waste Dump Osela

(Figure 7. Permeability of the First Transect Point 1 to 25 Waste Dump Osela) 

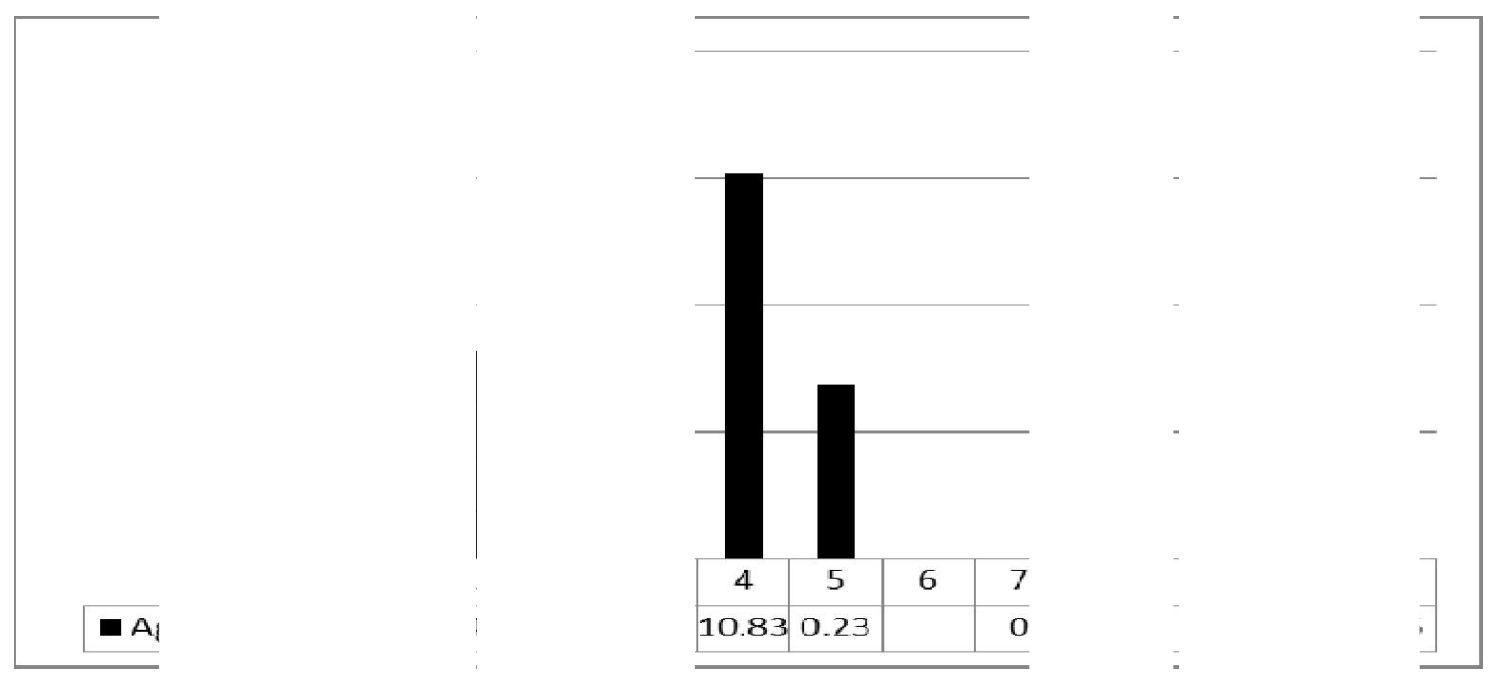

Gambar 8. Permeabilitas pada Transek Kedua Titik 1 sampai 11 Waste Dump Agus A

(Figure 8. Permeability of the First Transect Point 1 to 11Waste Dump Agus A)

Pada 2 meter puncak lereng permeabilitas tergolong sangat lambat, kemudian pada 6 meter berikutnya naik menjadi sedang, dan meningkat menjadi agak cepat pada 8 meter berikutnya, lalu terakhir pada kaki lereng menurun menjadi sangat lambat. Nilai rata-rata permeabilitas di lokasi Agus A sebesar $1.35 \mathrm{~cm} / \mathrm{jam}$ tergolong lambat kriteria (Hammer, 1978). Rata-rata permeabilitas pada transek ini lambat hal ini berkaitan erat dengan kondisi tanah yang kompak, lembab, padat, kemungkinan pada saat reklamasi terjadi pemadatan dalam penimbunan top soil. Menurut Susilo, A. (2010) biasanya pada tanah reklamasi sangat padat, tanah dengan kekompakan yang tinggi memiliki porositas atau pori-pori yang rendah sehingga mengakibatkan daya resap air tanah yang rendah. Permeabilitas tertinggi terjadi pada titik 4 sebesar $10.83 \mathrm{~cm} / \mathrm{jam}$ diidentifikasi pada tanah dengan tekstur lempung berdebu.Rendahnya permeabilitas terjadi pada titik 2 sebesar $0.02 \mathrm{~cm} / j a m$ diidentifikasi pada tanah dengan tekstur liat berdebu dan struktur gumpal.

\section{Lokasi Agus B}

Hasil pengukuran permeabilitas pada 5 titik di lokasi Agus B ditunjukkan pada (Gambar 9).

Pada 2 meter puncak lereng permeabilitas tergolong cepat, kemudian menurun menjadi lambat pada 4 meter berikutnya, lalu meningkat menjadi sangat cepat pada 6 meter berikutnya, dan terakhir pada jarak 10 meter menjadi sangat lambat.

Nilai rata-rata permeabilitas di lokasi Agus B sebesar $43.92 \mathrm{~cm} / \mathrm{jam}$ tergolong cepat kriteria (Hammer, 1978). Permeabilitas cepat pada transek ini kemungkinan karena secara visual terlihat tanah tersebut baru di olah, baru ditaburi kompos, tanahnya masih terbongkar. Menurut Rejntjes et. al. (2003) Pengolahan tanah dalam upaya memperbaiki keadaan tanah sangat berpengaruh terhadap kemampuan menahan air, aerasi, infiltrasi, dan evaporasi.

Permeabilitas tertinggi terjadi pada titik 3 sebesar $203.4 \mathrm{~cm} / j a m$ dan terendah dititik 5 hanya sebesar $0.11 \mathrm{~cm} / \mathrm{jam}$. Tingginya permeabilitas kemungkinan besar karena tanah ini terlihat baru dibongkar belum terjadi pemadatan struktur tanahnya remah yang mempunyai pori besar sehingga permeabilitas tinggi (Prijono, 2008). Rendahnya permeabilitas pada titik 5 diidentifikasi pada tanah dengan struktur granular.

\section{Lokasi Nala}

Hasil pengukuran permeabilitas pada 13 titik di lokasi Nala ditunjukkan pada (Gambar 10). 

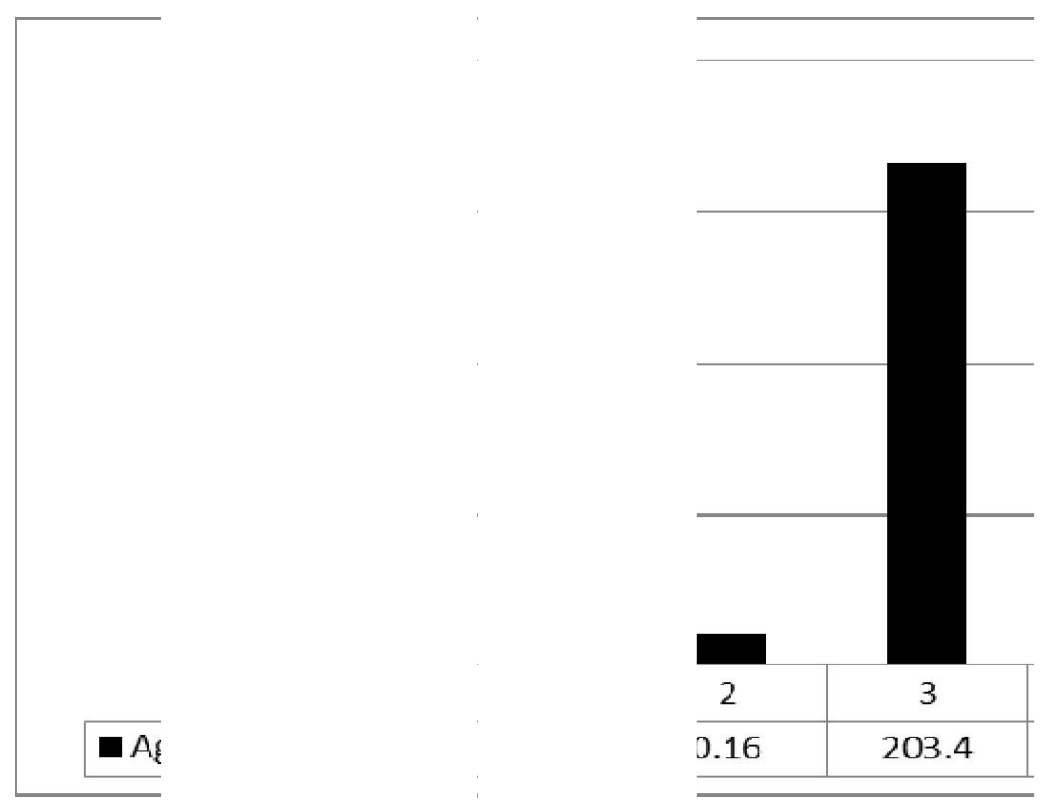

Gambar 9. Permeabilitas pada Transek Ketiga Titik 1 sampai 5 Waste Dump Agus B

(Figure 9. Permeability of the First Transect Point 1 to 5 Waste Dump Agus B)
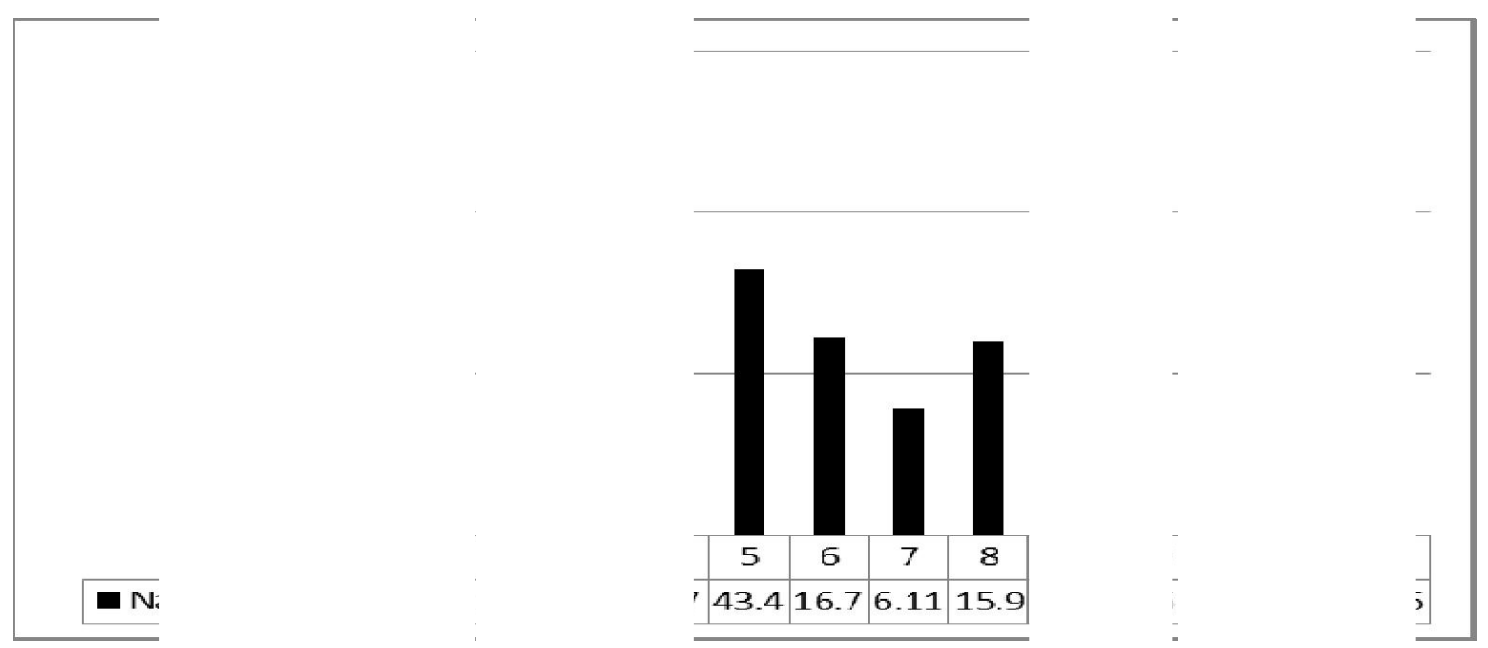

Gambar 10. Permeabilitas pada Transek Keempat Titik 1 sampai 13 Waste Dump Nala

(Figure 10. Permeability of the First Transect Point 1 to 13 Waste Dump Nala)

Pada 2 meter puncak lereng permeabilitas tergolong sangat cepat, lalu pada 4 meter menurun menjadi cepat, kemudian pada 6 meter menjadi sedang, selanjutnya pada 8 meter berikutnya meningkat menjadi sangat cepat, terakhir 26 meter di kaki lereng menjadi agak cepat. Nilai rata-rata permeabilitas di lokasi Nala sebesar $56.94 \mathrm{~cm} / \mathrm{jam}$ tergolong cepat (Hammer, 1978). Permeabilitas tertinggi terjadi pada ttitik pengukuran 4 sebesar 567 $\mathrm{cm} / \mathrm{jam}$, terendah pada titik pengukuran 3 yang hanya sebesar $4.31 \mathrm{~cm} / \mathrm{jam}$. Besarnya permeabilitas pada titik tersebut kemungkinan karena pengaruh vegetasi sehingga permukaan tanahnya banyak mengandung bahan organik, terlihat di lapangan tanah disini gembur tidak terlalu kering dan lembab serta mempunyai struktur granular. Menurut Hakim, dkk. (1986) struktur serta unsur organik lainya berperan dalam menaikkan laju permeabilitas. Rendahnya permeabilitas pada titik pengukuran mungkin disebabkan karena kondisi 
tanah permukaan yang terbuka tidak terdapat vegetasi yang banyak sehingga berpengaruh terhadap sumbangan bahan organik. Menurut Asdak, (2002) sistem perakaran dan serasah yang dihasilkan dapat membantu menaikkan permeabilitas tanah dan kapasitas infiltrasi.

\section{Pengaruh Reklamasi terhadap Infiltrasi dan Permeabilitas}

Secara keseluruhan nilai infiltrasi hasil pengukuran di lapangan mempunyai keragaman. Infiltrasi pada lokasi pengukuran Osela dan Nala tergolong sedang, Agus A dan Agus B lambat. Rata-rata infiltrasi di lokasi Osela dan Nala tergolong sedang karena keberadaan vegetasi seperti rumput, cover crop, sengon, dan trembesi (Osela); dan rumput, gamal, kemiri, sengon, dan cempaka (Nala) yang mampu memberikan sumbangan bahan organik pada lahan ini. Bahan organik ini memicu perkembangbiakan organisme dalam tanah sehingga menjadikan struktur tanah menjadi bagus, seperti teori sebelumnya, mikroorganisme banyak menciptakan pori-pori sehingga air mengalir lebih cepat. Sebaliknya, infiltrasi pada lokasi Agus A dan Agus $B$ tergolong lambat, kondisi tanah Agus $A$ saat pengukuran dilakukan, tanah pada lahan ini masih cenderung padat meskipun terdapat vegetasi seperti cover crop, sengon, dan trembesi, tetapi sangat sedikit mengandung bahan organik kemungkinan karena kondisi lereng yang sangat miring juga vegetasi rumput yang sedikit sehingga bahan organik terbawa pada saat terjadi hujan. Pada Agus B infiltrasi tergolong lambat karena keberadaan vegetasi rumput yang baru tumbuh belum bisa sepenuhnya melindungi tanah saat terjadi hujan sehingga pori-pori tanah mungkin tertutup.

\section{Pengaruh Reklamasi terhadap Permeabilitas}

Secara keseluruhan kondisi permeabilitas di lapangan mempunyai keragaman. Permeabilitas pada lokasi pengukuran Osela tergolong sedang sampai cepat, Agus A lambat, Agus B dan Nala tergolong cepat. Permeabilitas di lokasi Osela sedang cepat karena keberadaan vegetasi seperti rumput, cover crop, sengon, dan trembesi (Osela) dan rumput, gamal, kemiri, sengon, dan cempaka
(Nala) yang mampu memberikan sumbangan bahan organik pada kedalaman tanah $>5 \mathrm{~cm}$. Hal ini menjadikan struktur tanah menjadi bagus dan aktivitas perakaran dari vegetasi yang menjadikan pori-pori besar di lahan ini. Seperti teori sebelumnya, mikroorganisme banyak menciptakan pori-pori sehingga air mengalir lebih cepat. Sebaliknya, permeabilitas pada Agus A lambat karena permukaan tanahnya padat, tertutupnya pori-pori tanah mengakibatkan air mengalir menjadi lambat. Permeabilitas pada lokasi Agus B dan Nala tergolong cepat, kondisi ini kemungkinan karena bahan organik yang ada pada tanah permukaan masih berpengaruh pada kedalaman $>5 \mathrm{~cm}$ sehingga poripori tanah besar yang terbentuk oleh aktivitas perakaran dari vegetasi di lahan ini, yang mengakibatkan aliran menjadi tinggi.

\section{KESIMPULAN DAN SARAN}

\section{Kesimpulan}

Reklamasi dan revegetasi tambang emas memberikan pengaruh positif terhadap laju infiltrasi dan permeabilitas. Infiltrasi tertinggi terjadi pada waste dump Osela yaitu $163 \mathrm{~cm} / \mathrm{jam}$ dan permeabilitas tertinggi pada waste dump Nala A yaitu $567 \mathrm{~cm} / \mathrm{jam}$.

\section{Saran}

Perlu adanya penelitian lebih lanjut pada kedalaman tanah dibawah $10-20 \mathrm{~cm}$. Perlu penambahan bahan organik untuk memperbaiki struktur tanah. Perlu dilakukan pengamatan sifat fisik, kimia, dan biologi tanah pada setiap tanah reklamasi yang digunakan pada penelitian ini secara teratur dengan interval waktu tertentu untuk memonitor perkembangan sifat-sifat tanah pada masing-masing tanah reklamasi.

\section{DAFTAR PUSTAKA}

Anonimous, 2009. Undang-Undang Republik Indonesia nomor 4 Tahun 2009 tentang Pertambangan Mineral dan Batubara. www.hukumonline.com. 24 Oktober 2017. 
Arsyad, S. 2010. Konservasi Tanah dan Air. IPB Press, Bogor. pp. 472

Asdak, C. 2002. Hidrologi dan Pengelolaan Daerah Aliran Sungai. Gadjah Mada University Press: Yogyakarta.

Bachtiar, J. E. 2011. Pengaruh Konsentrasi Pupuk Daun dan Aplikasi Bakteri synechococcuc sp Terhadap Laju Fotosintesis dan Produksi Biomasa Tanaman Nilam. Skripsi Universitas Jember. Jember.

Hakim, N., M.Y. Nyakpa, A.M. Lubis, S.G. Nugroho, M.H. Diha, G.B.Hong, dan H.H. Bailey. 1986. Dasar-Dasar IImu Tanah. Universitas Lampung.

Hammer, W.I. 1978. Soil Conservation Report INS78/006. Technical Note No 7. Soil Research Institute, Bogor.

Hardjowigeno, S. 2007. IImu Tanah. Akademika Presindo. Jakarta. pp. 288.

Husain, J. 1993. The Use of The Guelph Pressure Infiltrometer In Laboratory and Field Research. Thesis. The Faculty of Graduate Studies, University of Guelph.

Irsyamudana. E. 2000. Dampak Kepadatan Penutupan Tanah dan Ketebalan Seresah terhadap Limpasan Permukaan dan Erosi di Sumberjaya Lampung. Skripsi. Fakultas Pertanian Brawijaya. Malang.

Kohnke, H. 1968. Soil Physics. New York: McGrawHill Inc.
Lee. R. 1990. Hidrologi Hutan. Universitas Gajah Mada.

Liedloff, A.C., J.A. Ludwing and M.B. Coughenour. 2003. Simulating Overland Flow and Soil Infiltration using an Ecological Approach. in David A Post (ed), Proc. Vol 2. Natural System, Modsim, Townsvile, P. 525-519

Prijono, Sugeng. 2008 :Evaluasi Kebutuhan Air Tanaman di 12 Kecamatan Wilayah Kabupaten Malang dengan Cropwat For Windows. AGRITEK VOL. 16 No. 4 Oktober 2008 Hal.600-780.

Reijntjes, C., B. Haverkort dan W. Bayer. 2003. Pertanian Masa Depan. Kanisius. Yogyakarta.

Sofyan, R.H., E.D. Wahjunie, dan Y. Hidayat. 2017. Karakterisasi Fisik dan Kelembaban Tanah Pada Berbagai Umur Reklamasi Lahan Bekas Tambang. Vol. 1 No.1 (7278).

Susanto. 2005. Dasar-Dasar IImu Tanah (Konsep dan Kenyataan). Penerbit Kanisius. Yogyakarta.

Susilo, A. 2010. Status Riset Reklamasi Bekas Tambang Batubara. Balai Besar Penelitian Dipterokarpa. Samarinda.

Uhland, R.E. and A.M. O'neal. 1951. Soil Permeability Determinations For Use In Soil and Water Conservations. SCS-TP101, 36 pp., liius, New York. 